\title{
PENGABDIAN KEPADA MASYARAKAT \\ PEMBERDAYAAN APARATUR DESA DALAM MENINGKATKAN KESADARAN MASYARAKAT TERHADAP URGENSI PAUD (RA) SERTA KELEMBAGAAN PAUD DI DESA CIKIDANG KECAMATAN BANTARUJEG KABUPATEN MAJALENGKA
}

\author{
Oleh: \\ Nursahidin ${ }^{1}$, Fahrudin Muhtarulloh ${ }^{2}$ \\ 1,2Universitas Swadaya Gunung Jati \\ 1nursahidin_sirod@yahoo.com
}

\begin{abstract}
Abstrak
Peyuluhan yang telah dilakukan ini secara khusus bertujuan untuk meningkatkan kesadaran masyarakat/ aparatur desa/ pengelola tentang pentingnya PAUD serta kelembagaannya. Dilihat dari beberapa indikator keberhasilan tujuan khusus ini sudah tercapai, diantaranya aparatur desa menjadi bagian dari pengurus yayasan serta pengelola PAUD akan membentuk yayasan untuk menaungi lembaganya. Tujuan jangka panjang penyuluhan ini adalah (1) meningkatkan angka partisipasi pendidikan anak usia dini. (2) memperkuat kelembagaan PAUD. (3) meningkatkan pengawasan dan pembinaan aparat desa terhadap lembaga PAUD.Target luaran yang diharapkan setelah pengabdian ini dilaksanakan adalah mempublikasikan hasil pengabdian melalui publikasi ilmiah, media masa, maupun yang sejenisnya. Dengan demikian diharapkan hasilnya dapat bermanfaat secara luas. Metode penyuluhan yang digunakan adalah ceramah (presentasi), diskusi (tanya jawab), dan pembinaan.
\end{abstract}

Kata Kunci: Aparatur Desa, PAUD, Kelembagaan, Yayasan

\section{Abstract}

The aim of the socialization is to increase a awareness of the community/ village apparatus/ manager about the importance of early childhood education and its institutions. Based on the several indicators, the goal was achieved. The village apparatus become part of the board of foundations and the PAUD managers will form a foundation to overshadow the institution. The long-term outcomes of this counseling are (1) increasing the participation rate of early childhood education. (2) strengthening the PAUD institution, and (3) improving the supervision and guidance of village apparatus toward the PAUD institution. The expected output is to publish the results of dedication through scientific publications, mass media, and the like. Therefore, it is expected that the results can be widely useful. The methods of socialization were lecturing, discussing, and coaching.

Keywords: Village Apparatus, Institution, Foundation

\section{PENDAHULUAN}

Kelembagaan sebuah instansi sangatlah penting mempengaruhi keberlangsungan instanssi tersebut, dimanapun instansinya dan besar ataupun kecilnya instansi tersebut. Hal ini tidak terkecuali dengan instansi yang berada di desa. Instansi yang bergerak dalam bidang pendidikan maupun instansi lainnya seperti instansi pertanian, baik formal maupun yang dikelola oleh masyarakat desa.

Mengingat bahwa pendidikan adalah merupakan asset penting bagi kemajuan sebuah bangsa, oleh karena itu setiap warga
Negara harus dan wajib mengikuti jenjang pendidikan, baik jenjang pendidikan anak usia dini, pendidikan dasar, pendidikan menengah maupun tinggi. Undang-undang Nomor 20 Tahun 2003 tentang Sistem Pendidikan Nasional, secara tegas menyatakan bahwa "Pendidikan anak usia dini (PAUD) adalah jenjang pendidikan sebelum pendidikan dasar yang merupakan suatu upaya pembinaan yang ditujukan bagi anak sejak lahir sampai dengan usia enam tahun yang diberikan melalui pemberian rangsangan pendidikan untuk membantu pertumbuhan dan perkembangan jasmani 
dan rohani agar anak memiliki kesiapan dalam memasuki pendidikan lebih lanjut". Selanjutnya dinyatakan pula bahwa pendidikan anak usia dini dapat diselenggarakan pada jalur formal (Taman Kanak-kanak/ Raudathul Athfal) jalur nonformal (Taman Penitipan Anak, Kelompok Bermain, dan bentuk lain yang sederajat), dan pada jalur informal (melalui pendidikan keluarga atau lingkungan).

Aparatur desa diharapkan dapat membantu meningkatkan pengelolaan lembaga pendidikan yang sudah berada ditengah-tengah masyrakat Cikidang seperti PAUD. Sebagaimana diatur dalam UUD 45 bahwa pendidikan adalah hak bagi setiap warga negara dan penyelenggaraan pendidikan dibawah pengawasan dan pembinaan pemerintah pusat sampai pemerintah daerah, dalam tingkat desa adalah pemerintahan desa. Salah satu bentuk partisipasi aparat desa dalam hal ini adalah membantu pembentukan yayasan yang dapat memayungi lembaga tersebut.

\section{Analisis Situasi}

Bagaimana dengan kelembagaan bidang pendidikan anak usia dini dan di Desa Cikidangn Kecamatan Bantarujeg Kabupaten Majalengka. Berdasarkan studi awal yang penulis lakukan yang berupa wawancara (audiensi) dengan Kepala Urusan Umum (Kaur Umum) diperoleh data bahwa baik TK, RA maupun belum dinaungi oleh sebuah yayasan. Padahal jika dilihat dari peraturan pemerintah pusat baik lembga pendidikan maupun lembaga pertanian harus bernaung pada sebuah yayasan. Hal ini tentu akan memberikan dampak yang baik bagi lembaga itu sendiri, jika kedua lembaga yang ada ini dibentuk sebuah yayasan yang sama ataupun berbeda. Namun dalam hal ini, menurut Kaur Umum di desanya masih memerlukan penerangan dan penjelasan lebih lanjut mengenai pembentukan yayasan.

Berdasarkan hasil di atas, sangat bermanfaat dilakukan penyuluhan tentang penguatan kelembagaan dalam bidang pendidikan dan pertanian demi mendorong pendirian sebuah yayasan yang menaungi lembaga tersebut. Oleh karena itu penulis berencana melakukan hal tersebut sebagai bentuk pengabdian dosen sesuai kewajiban Tri Dharma Perguruan Tinggi bagi seorang dosen.

Mengacu pada permasalahan yang diajukan untuk dipecahkan, maka tujuan kegiatan P2M ini secara umum adalah untuk meningkatkan kesadaran masyarakat dan aparatur desa dalam hal memperkuat kelembagaan yang ada di desa Cikidang.

Kegiatanan Pengabdian Kepada Masyarakat (P2M) ini akan memberikan kontribusi positif pada kelembagaan PAUD di desa Cikidang. Kelembagaan PAUD akan menjadi lebih baik dan mendapatkan bantuan dari pemerintah setelah dinaungi yayasan yang berbadan hukum.

Kedepan pengajar PAUD dapat diajukan untuk memperoleh sertifikasi guru. Anggota akan dapat mengajukan bantuan dari pemerintah secara rutin dan berkala.

\section{METODE PELAKSANAAN}

\section{Kerangka dan Realisasi Pemecahan Masalah}

Berangkat dari masalah yang dijelaskan pada pendahuluan, untuk memecahkan masalah tersebut penulis telah melakukan penyuluhan di Balai Desa Cikidang dengan dihadiri oleh Kepala Desa serta semua jajaran aparatnya yang bisa hadir. Berangkat dari permasalahan yang dihadapi, disusun berbagai alternatif pemecahan yang feasible. Selanjutnya dari berbagai alternatif yang mungkin tersebut, dipilih alternatif yang paling mungkin dilaksanakan. Alternatif yang paling tepat dalam memecahkan masalah yang dihadapi masyarakat khususnya urgensi kelembagaan PAUD dan dibawah sebuah yayasan yang menaunginya demi kemajuan kedua lembaga tersebut di desa Cikidang. Adapun kerangka pemecahan masalahnya adalah sebagai berikut:

1. Mengidentifikasi dan meniventarisir masalah yang dihadapi desa Cikidang terkait PAUD dan kelembagaannya.

2. Membuat berbagai pilihan penyelesaian masalah, yaitu penyuluhan atau penyuluhan.

3. Penyelesaian masalah yang lebih tepat untuk masalah kelembagaan PAUD di desa Cikidang adalah penyuluhan. Karena penyuluhan terhadapt masyarakat, pelaku pendidikan PAUD dan aparat desa terkait kelembagaan PAUD dianggap lebih efektif.

4. Pelaksaan penyuluhan bertempat di Balai Desa Cikidang. Peserta penyuluhan terdiri dari aparatur desa, pelaku pendidikan PAUD desa Cikidang. Adapun metode yang digunakan adalah metode 
ceramah dan diskusi. Secara umum acara berjalan dengan baik dan lancar. Dua minggu setelah penyuluhan tim pengabdi mendatangi salah satu PAUD yang ada di desa Cikidang untuk sharing dengan pengelola terkait optimalisasi kelembagaan PAUD

Tim pengabdian ini terdiri dari dua orang dosen, pak Nursahidin sebagai ketua pengabdian sudah memiliki pengetahuan dan pengalaman yang cukup dalam pengurusan pendirian yayasan. Fahrudin Muhtarulloh sudah mempelajari dan memahami mengenai bagaimana seharusnya lembaga PAUD dalam hal ini RA harus dikelola. Adapun materi yang akan diberikan adalah:

1. Pentingnya pendidikan anak usia dini (PAUD) bagi anak usia $2-6$ tahun.

2. Urgensi kelembagaan PAUD dibawah naungan sebuah yayasan.

3. Prosedur pendirian Yayasan.

4. Optimalisasi peran Aparatur desa dalam membantu pembentukan Yayasan yang menaungi PAUD di desa Cikidang.

\section{Bentuk Pelaksanaan Kegiatan}

Bentuk pelaksanaan kegiatan pengabdian kepada masyarakat di desa Cikidang pada tahun ini adalah penyuluhan pembentukan kelembagaan PAUD yaitu yayasan yang menaungi PAUD. Besar harapan penulis setelah penyuluhan ini selesai dilaksanakan aparatur desa dan pengelola PAUD pengetahuan mengenai pentingnya sebuah yayasan yang akan menaungi PAUD dan atau desa Cikidang. Tujuan akhirnya adalah aparatur desa dan pengelola PAUD dapat membentuk Yayasan yang menaungi PAUD.

\section{Waktu Efektif Pelaksanaan}

Pelaksanaan kegiatan penyuluhan ini membutuhkan alokasi waktu selama 4 (empat) bulan, dimulai sejak penandatanganan ijin kegiatan oleh pihak Universitas. Berbagai kegiatan operasional dan terperinci sebagaimana tampak pada Tabel 1.

Tabel 1. Jadwal Pelaksanaan Kegiatan

\begin{tabular}{cl}
\hline Bulan ke & \multicolumn{1}{c}{ Uraian Kegiatan } \\
\hline 1 & Penyusunan Proposal \\
\cline { 2 - 2 } 2 & Persiapan Pelaksanaan \\
\hline 3 & Pelaksanaan Pelatihan \\
\hline & Pembinaan Pengelola Lembaga PAUD \\
\hline
\end{tabular}

\section{Metode Kegiatan}

Pengabdian penyuluhan urgensi PAUD dan kelembagaannya ini dilaksanakan dengan dua metode, yaitu:

1. Metode Ceramah (Presentasi).

Materi yang disampaikan adalah:

a. Pentingnya PAUD sebelum lanjut ke sekolah dasar.

b. Pentingnya sebuah yayasan yang memayungi PAUD di desa Cikidang. Prosedur Pembentukan Yayasan.

2. Metode Diskusi/ Tanya Jawab

Peserta diberi kesempatan untuk bertanya atau berdiskusi tentang kelembagaan PAUD, pembentukan yayasan, dan urgensi PAUD.

\section{HASIL DAN PEMBAHASAN}

Pelaksanaan kegiatan dibagi dalam 2 tahap, yaitu penyuluhan dan kunjungan lanjutan. Persiapan peyuluhan dilakukan pada bulan pertama dimulai dari penentuan lokasi pengabdian. Selanjutnya observasi awal dilakukan pada desa Cikidang yang menghasilkan data bahwa lokasi tersebut cocok dengan tema pengabdian penulis. Sesuai dengan hasil observasi awal tersebut maka diputuskan bahwa Desa Cikidang sebagai tempat pengabdian. Selanjutnya khalayak sasaran kegiatan adalah aparat Desa Cikidang, pengelola PAUD Desa Cikidang, dan Masyarakat yang mempunyai anak umur $3-5$ tahun. Selanjutnya ditentukan waktu dan tempat kegiatan penyuluhan yaitu tanggal 2 Maret 2016 bertempat di Balai Desa Cikidang namun apabila ada halangan maka akan menyesuaikan dengan kegiatan di Desa Cikidang. Pada tanggal 24 Februari 2016 sosialisasi materi penyuluhan sekaligus persiapan terakhir pelaksanaan kegiatan. Dari sosialisasi yang dilakukan pada tanggal 
tersebut (24 Februari 2016) terdapat sedikit perubahan tempat kegiatan akan tetapi tidak untuk waktu pelaksanaan (tetap tanggal 2 Maret 2016). Perubahan yang dimaksud adalah tempat pelaksanaan yang semula akan menggunakan Balai Desa Cikidang berubah di kantor desa darurat yaitu di rumah penduduk mengingat sedang dilakukan Renovasi (pembangunan) Balai Desa Cikidang.

Pada tanggal 2 Maret 2016 team pengabdi yang berjumlah 2 orang datang ke Kantor Desa Cikidang dengan membawa tambahan sarana/ prasarana berupa laptop dan infokus (proyektor) dari jam 13.00 sampai dengan selesai. Acara pertama diawali dengan sambutan dan penerimaan dari Kepala Desa Cikidang. Selanjutnya pengenalan profil Unswagati serta dosen-dosen yang terlibat dalam penyuluhan ini yang dibawakan. Setelah itu pemberian materi pertama oleh Bapak Fahrudin Muhtarulloh, M.Sc. selama kurang lebih 60 menit. Materi pertama yang disampaikan adalah Urgensi Pendidikan Anak Usia Dini (PAUD) serta Periode Emas Perkembangan Anak. Setelah materi selesai disampaikan, dilanjutkan dengan sesi diskusi selama 15 menit. Pada sesi ini terlaksana dengan aktif, para peserta penyuluhan berpartisipasi dalam sesi diskusi, sehingga diskusi berjalan dengan hidup dan mengalir. Dari sesi diskusi ini diperloleh informasi tambahan bahwa terdapat sebuah yayasan yang sudah dibentuk yaitu Yayasan Al Mubtadiin Al - Aziz, belum berjalan sebagaimana mestinya atau boleh dikatakan vakum semenjak tahun 2008.

Pada tanggal 13 Maret 2016 kami dari tim pengabdian menindaklanjuti hasil diskusi pada penyuluhan tanggal 2 Maret 2016. Pada pukul 09.30 tim pengabdian sampai di Kantor Balai Desa Cikidang (baru selesai pembangunan) dan diterima langsung oleh Kepala Desa Cikidang. Selama 90 menit ketua pengabdian yaitu Pak Nursahidin, S.Sos., M.Si berdiskusi dengan Kepala Desa terkait permasalah sebuah Yayasan yang berada dilingkup kerja bapak Kepala Desa. Yayasan tersebut dinilai belum melakukan aktivitas yang nyata (vakum) terkait pengelolaan dan pengembangan PAUD yang dinaunginya sejak tahun 2008. Bapak Ade Rohendi selaku Kepala Desa optimis kami dapat membantu menyelesaikan permasalahan yang ada terkait kelembagaan yayasan dan pendirian yayasan baru.

Setelah diskusi dengan pak Kepala Desa tim bergerak ke Yayasan Al - Mubtadiin Al -
Aziz yang memerlukan pembinaan dalam hal pengelolaan serta pengembangan. Kegiatan ini adalah sesi terakhir dari pelaksanaan pengabdian di desa Cikidang Kecamatan Bantarujeg Kab. Majalengka. Penyambutan tim pengabdi oleh pihak yayasan diwakili oleh ketua yayasan dan sekertaris yayasan. Kurang lebih selama 90 menit diskusi yang dipandu oleh Bapak ketua Pak Nursahidin, S.Sos.,M.Si. Diskusipun berjalan lancar dan hidup, banyak hal yang dibahas terkait tata cara pengelolaan dan pengembangan yayasan. Pengelolaan yayasan melaui ketua yayasan mengucapkan rasa syukur dan berterimakasih atas informasi dan tukar pikiran serta wawasan yang disampaikan oleh tim pengabdi.

\section{Hasil Pelaksanaan Kegiatan}

Adapun Hasil dari kegiatan pengabdian ini dapat disusun sebagai berikut:

1. Masyarakat semakin sadar akan pentingnya pendidikan anak usia dini bagi anak-anaknya.

2. Pengelola PAUD menyadari akan pentingnya pembentukan yayasan untuk menaungi lembaganya sehingga dapat mengembangkanlembaganya baik dari segi fisik, guru, dan status lembaganya.

3. Pengelola Yayasan Al - Mubtadiin Al Aziz menjadi sadar bahwa setelah didirikan yayasan harus dikelola dengan baik dan dikembangkan demi kemajuan lembaganya.

4. Aparatur desa dapat membantu mendorong peningkatan pengelolaan yayasan dan juga mendorong pendirian yayasan baru.

\section{Indikator dan Faktor Pendukung Keberhasilan Kegiatan}

Secara umum penyuluhan ini berjalan lancar, hal ini ditunjukkan dengan sikap peserta yang sangat antusiasi mengikuti penyuluhan. Selain itu indikator keberhasilan kegiatan ini adalah peserta penyuluhan menyadari dengan baik arti pentingnya PAUD serta kelembagaannya hal ini ditunjukkan dengan pergerakan yang aparatur desa beserta pengelola PAUD lakukan demi terwujudnya sebuah yayasan baru dan atau pengelolaan yayasan menjadi lebih baik lagi ke depan. Indikator keberhasilan penyuluhan ini dijelaskan lebih detail sebagai berikut:

1. Lebih dari $75 \%$ Peserta menyadari pantingnya PAUD dan berniat akan memasukka anak-anaknya secepatnya ke PAUD. 
2. Aparatur Desa berinisiatif menjadi dewan Pembina Yayasan Al - Mubtadiin Al Aziz, demi membantu pengelolaan dan pengembangan yayasan tersebut.

3. Ketua Yayasan Al - Mubtadiin Al - Aziz akan melakukan perombakan kepengurusan demi memajukan dan mengembangkan yayasan ke depan.

Keberhasilan di atas dicapai berkat dukungan dari Bapak Kepala Desa beserta jajarannya serta dukungan dari tokoh masyarakat Desa Cikidang. Bapak Kepala Desa Cikidang menyambut baik acara ini dan mengucapkan syukur dan terimakasihnya kepada tim pengabdi dan juga kepada LPM Unswagati dalam hal ini selaku penganggung jawab kegiatan.

\section{Faktor Penghambat Kegiatan}

Meskipun secara umum acara penyuluhan ini berjalan dengan lancar, tetapi masih ada kekurangan dalam kegiatan penyuluhan ini. Salah satunya adalah kurangnya tokoh penggerak yang mampu mengembangkan yayasan yang akan ataupun sudah dibentuk. Kurangnya kepekaan ketua yayasan pada perkembangan yayasannya. Selain itu kurangnya informasi yang maksimal mengenai pengelolaan PAUD. Kekurangan tersebut tidak begitu berarti karena dapat segera diantisipasi oleh kami.

\section{SIMPULAN DAN SARAN}

\section{Simpulan}

Kegiatan Penyuluhan Pengabdian Kepada Masyarakat Pemberdayaan Aparatur Desa Dalam Meningkatkan Kesadaran Masyarakat Terhadap Urgensi Paud (Ra) Serta Kelembagaan Paud (Ra) Di Desa Cikidang Kecamatan Bantarujeg Kabupaten Majalengka Cikidang berjalan dengan lancar. Kesadaran peserta akan pentingnya PAUD dan pengelolaan kelembagaannya semakin meningkat. Semua peserta antusias dan merasakan manfaat penyuluhan.

\section{Saran}

Penyuluhan serupa dapat dilaksanakan kembali pada desa lain yang memiliki masalah yang sama terkait tema pengabdian penulis. Besar harapan penulis ke depan tidak ditemukan lagi permasalahan seperti ini ditempat manapun. Semoga pengelolaan PAUD menjadi semakin baik, profesional dan maju.

\section{DAFTAR PUSTAKA}

Hadis, F.A. (1996). Psikologi Perkembangan Anak.Jakarta: Proyek Pendidikan Tenaga Guru Ditjen Dikti Depdikbud.

Halpern, R., \& Fiqueiras, A. C. M. (2004). Environmental influences on child mental health. Journal de Peditria, vol. 80 (2), 104-110.

Hurlock, Elizabeth. B. (1978). Child Development, Sixth Edition.New York: Mc. Graw Hill, Inc.

Hurlock, Elizabeth B. 1978. Perkembangan Anak Jilid 1, Erlangga, Jakarta

Hurlock, Elizabeth B. 1978. Perkembangan Anak Jilid 2, Erlangga, Jakarta

Permendiknas no 58 tahun 2009

Rubin, K. H., \& Burgess, K. (2002). Parents of aggressive and withdrawn children. In M. Bornstein (Ed.), Handbook of Parenting (2nd ed., Vol. 1, 383-418). Hillsdale, NJ: Erlbaum.

Rubin, K. H., Burgess, K. B., Dwyer, K. M., \& Hastings, P.D. (2003). Predicting preschooler's externaalizing behaviors from toddler temperament, conflict, and maternal negativity. Developmental Psychology, 39, 164176.

Undang-Undang Dasar 1945

Undang-Undang Nomor 20 Tahun 2003 tentang Sistem Pendidikan Nasional

Undang-Undang Nomor 6 Tahun 2014 tentang Desa 